\title{
Characterization of hydrochars produced by hydrothermal carbonization of rice husk
}

\author{
D. Kalderis ${ }^{1}$, M. S. Kotti ${ }^{1}$, A. Méndez ${ }^{2}$, and G. Gascó ${ }^{3}$ \\ ${ }^{1}$ Department of Environmental and Natural Resources Engineering, Technological and Educational Institute of Crete, Chania, \\ 73100 Crete, Greece \\ ${ }^{2}$ Departamento de Ingeniería de Materiales, E.T.S.I. Minas, Universidad Politécnica de Madrid, C/Ríos Rosas no. 21 , 28003 \\ Madrid, Spain \\ ${ }^{3}$ Departamento de Edafología, E.T.S.I. Agrónomos, Universidad Politécnica de Madrid, Ciudad Universitaria, 28004 Madrid, \\ Spain
}

Correspondence to: D. Kalderis (dkalderis@ chania.teicrete.gr)

Received: 24 February 2014 - Published in Solid Earth Discuss.: 4 March 2014

Revised: 25 April 2014 - Accepted: 29 April 2014 - Published: 11 June 2014

\begin{abstract}
Biochar is the carbon-rich product obtained when biomass, such as wood, manure or leaves, is heated in a closed container with little or no available air. In more technical terms, biochar is produced by so-called thermal decomposition of organic material under limited supply of oxygen $\left(\mathrm{O}_{2}\right)$, and at relatively low temperatures $\left(<700^{\circ} \mathrm{C}\right)$. Hydrochar differentiates from biochar because it is produced in an aqueous environment, at lower temperatures and longer retention times. This work describes the production of hydrochar from rice husks using a simple, safe and environmentally friendly experimental set-up, previously used for degradation of various wastewaters. Hydrochars were obtained at $200{ }^{\circ} \mathrm{C}$ and $300^{\circ} \mathrm{C}$ and at residence times ranging from 2 to $16 \mathrm{~h}$. All samples were then characterized in terms of yield, surface area, $\mathrm{pH}$, conductivity and elemental analysis, and two of them were selected for further testing with respect to heating values and heavy metal content. The surface area was low for all hydrochars, indicating that porous structure was not developed during treatment. The hydrochar obtained at $300^{\circ} \mathrm{C}$ and $6 \mathrm{~h}$ residence times showed a predicted higher heating value of $17.8 \mathrm{MJ} \mathrm{kg}^{-1}$, a fixed carbon content of $46.5 \%$ and a fixed carbon recovery of $113 \%$, indicating a promising behaviour as a fuel.
\end{abstract}

\section{Introduction}

Subcritical water is hot water $\left(100-374{ }^{\circ} \mathrm{C}\right)$ under enough pressure to maintain the liquid state. It is an environmentally friendly and inexpensive solvent that exhibits a wide range of properties that renders it very effective in solvating and decomposing moderately polar or non-polar substances from a wide range of environmental matrices. Subcritical water can decompose naturally occurring substances and materials, such as complex amino acids, proteins and carbohydrates (sucrose, fructose and sorbose), sodium alginate, and brown coal, to produce more valuable and useful products. Additionally, subcritical water has been proved to decompose hazardous organic substances and materials such as pentachlorophenol (PCP), fluorochemicals, dioxins, polycyclic aromatic hydrocarbons (PAHs), polychlorinated biphenyls (PCBs) and polyvinyl chloride (PVC) (Kalderis et al., 2008, and references therein).

The hydrothermal treatment of biomass at temperatures in the range of $100-374^{\circ} \mathrm{C}$ gives rise to water-soluble organic substances and a carbon-rich solid product, commonly known as hydrochar (Sevilla and Fuertes, 2009). Typically, the main components of biomass resources are 40-45 wt \% cellulose, $25-35 \mathrm{wt} \%$ hemicellulose, $15-30 \mathrm{wt} \%$ lignin and up to $10 \mathrm{wt} \%$ for other compounds (Toor et al., 2011). The treatment of biomass in subcritical water has received considerable attention over the last few years. The degradation mechanisms of lignin, cellulose and hemicellulose during hydrothermal treatment and the effect of 
the experimental parameters (residence time, temperature, type of biomass) have been thoroughly described elsewhere (Sevilla and Fuertes, 2009; Jamari et al., 2012; Wahyudiono et al., 2012; Wiedner et al., 2013; Gao et al., 2013; Parshetti et al., 2013; Lu et al., 2013). The products obtained during treatment are gases (about $10 \%$ of the original biomass, mainly $\mathrm{CO}_{2}$ ), bio-oil consisting primarily of sugars, acetic acid, and other organic acids and the solid product (char), which contains about $41-90 \%$ of the mass of the original feedstock. The produced char has a higher energy density and is more hydrophobic than the original biomass (Tufiq Reza et al., 2013).

Compared to other thermochemical processes such as pyrolysis, hydrogenation or gasification, aqueous conversion using subcritical water has the significant advantage of not requiring a drying process for feedstock and therefore can be conducted at high moisture content typical of biomass feedstocks. The hydrothermal carbonization temperature is usually much lower than that of pyrolysis, gasification, and flash carbonization. The water present can be used as the reaction solvent, whereas at the same time some off-gases, such as $\mathrm{CO}_{2}$, nitrogen oxides, and sulfur oxides, are dissolved in water, forming the corresponding acids and/or salts, making further treatment for air pollution possibly unnecessary. Finally, it is an environmentally friendly method as it requires no additives and in most cases is simple to set up and operate.

Compared to hydrochars, biochars produced through conventional pyrolysis methods have been more thoroughly applied and tested. Research on the applications of hydrochar is still in its early stages. Lately, hydrochars have been tested as soil conditioners and heavy metal immobilization means (Abel et al., 2013; Wagner and Kaupenjohann, 2014), as electrochemical supercapacitor electrode materials (Ding et al., 2013a, 2013b) and as anode materials for lithium ion batteries (Unur et al., 2013), with promising results. Ongoing work also focuses on their environmental impact and compatibility with agricultural and horticultural systems (Gajic and Koch, 2012; Busch et al., 2013; Bargmann et al., 2013).

Around $20 \%$ of the whole rice grain weight is rice husk. In 2008 the world rice grain production was 661 million tons, and consequently 132 million tons of rice husk were also produced. While there are some established uses for rice husk, it is still considered a waste product in the rice mill industry and it is often either burned in the open or disposed of in landfills. Rice husk has been extensively studied for the production of activated carbon through conventional pyrolysis routes (Kalderis et al., 2008, and references therein). However, the studies that deal with hydrothermal carbonization of rice husk are few. The scope of this study was to use a simple, safe, effective, environmentally friendly method to produce hydrochars from rice husk and characterize the products. Two of the produced hydrochars were selected, and their behaviour as fuels was examined.
Table 1. Properties of the rice husk (used in this study) and rice husk ash.

\begin{tabular}{ll}
\hline Rice husk & \\
\hline Moisture (\%) & 4.2 \\
Ash content (\%) & 16.1 \\
Volatile matter (\%) & 62 \\
Carbon (\%) & 36.1 \\
Fixed carbon (\%) & 17.7 \\
Higher heating value $\left(\mathrm{MJ} \mathrm{kg}^{-1}\right)$ & 15.1 \\
\hline $\mathrm{Rice}^{2}$ husk ash & $\mathrm{wt} \%$ \\
\hline $\mathrm{SiO}_{2}$ & 84.7 \\
$\mathrm{~K}_{2} \mathrm{O}$ & 2.51 \\
$\mathrm{CaO}$ & 0.74 \\
$\mathrm{Al}_{2} \mathrm{O}_{3}$ & 0.36 \\
$\mathrm{Na}_{2} \mathrm{O}$ & 0.20 \\
$\mathrm{MgO}^{\mathrm{P}_{2} \mathrm{O}_{5}}$ & 0.76 \\
$\mathrm{SO}_{3}$ & 0.62 \\
$\mathrm{Fe}_{2} \mathrm{O}_{3}$ & 0.38 \\
$\mathrm{Cl}$ & 0.28 \\
\hline
\end{tabular}

\section{Materials and methods}

Rice husk (RH) was obtained from Janta Rice Mill in Gurdaspur $\left(32.0333^{\circ} \mathrm{N}-75.40^{\circ} \mathrm{E}\right)$ in India. Rice husk was initially washed thoroughly with water to remove any impurities, dried at $110^{\circ} \mathrm{C}$ for $6 \mathrm{~h}$ and then ground with a microhammer cutter mill and sieved to a 32-mesh $(500 \mu \mathrm{m})$ particle size. The properties of the feedstock material are shown in brief in Table 1 and described in detail in Kalderis et al. (2008).

The experiments described here are under static conditions: no flow is required and no additional use of water. Additionally, monitoring of the process is not essential, since the oven can be pre-set at the required temperature and residence time. Finally, no pumping system is needed to maintain the system pressure, since pressure is automatically controlled by the steam/water equilibrium inside the reactor cell. The experimental set-up is described in detail in Kalderis et al. (2008) and Daskalaki et al. (2011). Briefly, one type of small laboratory reactor was used for hydrothermal treatment studies. The $25 \mathrm{~mL}$ reactors were constructed from $(6$ inches long, 0.64 inches i.d.) 316 stainless steel pipe with male national pipe threads (npt) and female end caps sealed with Teflon tape (Swagelok Company, USA).

A sample of the raw material was mixed with distilled water at a ratio of approximately $1 / 5$. The mixture was then stirred and heated to become homogenized and impregnated at a temperature of $85^{\circ} \mathrm{C}$ until a thick uniform paste was obtained. A sample of wet rice husk paste ( $\sim 75 \%$ moisture) was weighed before placing inside the reactor. Each reactor was loaded with $25 \mathrm{~g}$ of wet paste. This procedure left $\sim 5 \mathrm{~mL}$ of headspace in the cell. All static (non-flowing) reaction 
cells must contain a sufficient headspace so that the pressure inside the cell is controlled by the steam/liquid equilibrium. A full cell must never be used since the pressures could reach several thousand bar. The reactors were placed in a (pre-heated at the required temperature) gas chromatography oven (Hewlett-Packard 5890, series II) for heating. Zero time was taken when the reactors were placed in the oven. The experiments were performed at 200 and $300^{\circ} \mathrm{C}$ and residence times of 2, 4, 6, 8, 12 and $16 \mathrm{~h}$ (a total of 12 hydrochars). All runs were performed in triplicate. At the end of each experimental time, each reactor was removed from the oven and was allowed to cool in room temperature. The solid product (hydrochar) was recovered by filtration, washed with acetone and then with distilled water to remove all traces of acetone and air-dried for $24 \mathrm{~h}$. From now on, the hydrochars produced will be referred to as $\mathrm{H}$-temperature-residence time, e.g. H200-2 for the sample obtained at $200^{\circ} \mathrm{C}$ and $2 \mathrm{~h}$ residence time.

\section{Analysis and characterization}

The hydrochar yield was determined as the ratio of the produced hydrochar weight (after washing and drying) to the dry weight of rice husk subjected to hydrothermal treatment:

Hydrochar yield $(\%)=\left(W_{2} / W_{1}\right) \times 100$,

where $W_{1}$ is the dry weight of the rice husk sample prior to the treatment and $W_{2}$ is the hydrochar weight.

For measuring $\mathrm{pH}$ and electrical conductivity (EC) of hydrochars, suspensions of $0.01 \mathrm{moll}^{-1} \mathrm{CaCl}_{2}$ and distilled $\mathrm{H}_{2} \mathrm{O}(1: 5)$ were prepared. The mixtures were shaken for $1 \mathrm{~h}$ on a low-speed shaker at room temperature. After sedimentation of hydrochar material for another hour, $\mathrm{EC}$ and $\mathrm{pH}$ were determined in the supernatant (Wiedner et al., 2013). Hydrochar nitrogen adsorption analysis to determine BET surface area and pore structure was carried out at $77 \mathrm{~K}$ in a Micromeritics Tristar 3000. The content in C, H, N and S was analysed by an elemental microanalyser LECO CHNS-932, and the oxygen content was determined by difference. The parameters of yield, residence time and specific surface area were used to determine the optimum preparation conditions and the corresponding two hydrochar samples (one at each experimental temperature) to analyse further. As a result, the analyses described below were only applied to the selected hydrochars.

Metal content $(\mathrm{Cu}, \mathrm{Ni}, \mathrm{Zn}, \mathrm{Cd}$, and $\mathrm{Pb})$ was determined using a Perkin Elmer 2280 atomic absorption spectrophotometer after sample extraction by digestion with 3 : $1(v / v)$ concentrated $\mathrm{HCl} / \mathrm{HNO}_{3}$ following USEPA-3051a method (USEPA, 1997). The theoretical higher heating value $\left(\mathrm{HHV}_{p}\right)$ was calculated using an empirical correlation devel-

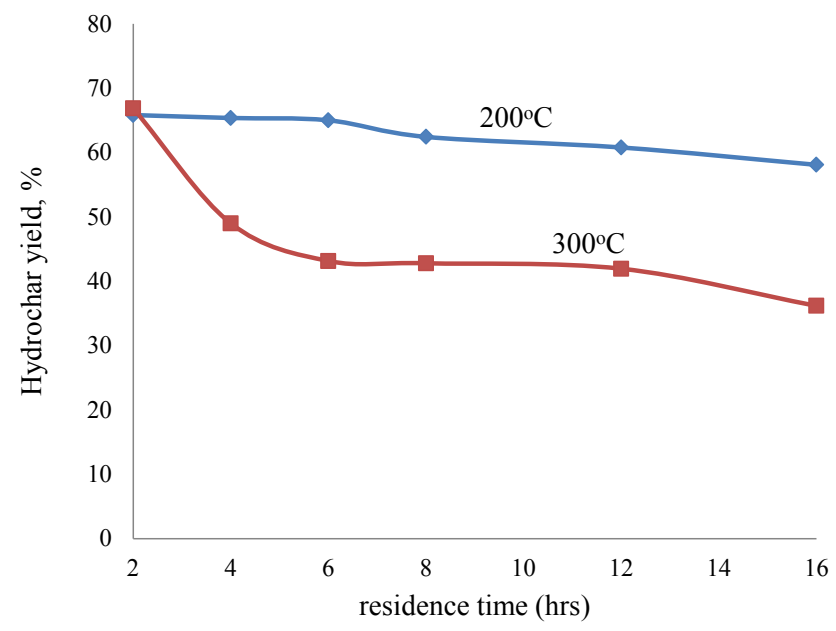

Figure 1. Hydrochar yields.

oped by Channiwala and Parikh (2002):

$\mathrm{HHV}_{\text {predicted }}\left(\mathrm{MJ} \mathrm{kg}^{-1}\right)=0.3491 \mathrm{C}$

$+1.1783 \mathrm{H}+0.1005 \mathrm{~S}-0.1034 \mathrm{O}-0.0015 \mathrm{~N}-0.0211 \mathrm{~A}$.

Equation 2 is used to predict the $\mathrm{HHV}$, where $\mathrm{C}, \mathrm{H}, \mathrm{S}, \mathrm{O}$, $\mathrm{N}$, and A represent the weight percentages of carbon, hydrogen, sulfur, oxygen, nitrogen, and ash in hydrochars, respectively (Channiwala and Parikh, 2002). Kang et al. (2012) and $\mathrm{He}$ et al. (2013) used this formula, and the relative error between the calculated and predicted values was less than $6 \%$. The selected hydrochars were also subjected to derivative thermogravimetric analysis (TG-dTG) in a Labsys Setaram thermobalance under air atmosphere and $15^{\circ} \mathrm{C} \mathrm{min}^{-1}$ heating rate. Proximate analysis was performed in the same Labsys Setaram thermobalance using $\mathrm{N}_{2}$ atmosphere and $30{ }^{\circ} \mathrm{C} \mathrm{min}^{-1}$ heating rate. Moisture content was calculated as the weight loss from the initial temperature to $150^{\circ} \mathrm{C}$. The volatile fraction $(\mathrm{VM})$ was determined as the weight loss from $150^{\circ} \mathrm{C}$ to $600^{\circ} \mathrm{C}$ under $\mathrm{N}_{2}$ atmosphere. At this temperature, air was introduced in order to determine the ash content. The fixed carbon percentage content was calculated as $100 \%$ - volatile matter percentage content - ash percentage content. Fixed carbon recovery is the percent of the fixed carbon content in the biomass that is maintained in the final processed product. It is an indication of the carbon sequestration potential and was determined as follows:

Fixed $\mathrm{C}$ recovery $(\%)=$

(\% of fixed $\mathrm{C}$ in hydrochar $/ \%$ of fixed $\mathrm{C}$ in rice husk)

$\times \%$ yield.

\section{Results and discussion}

The effect of temperature and residence time in hydrochar yield is presented in Fig. 1. It can be seen that hydrochar 
Table 2. Characterization of the hydrochar samples obtained at 200 and $300^{\circ} \mathrm{C}$.

\begin{tabular}{lcrrrrrrrr}
\hline & $\mathrm{pH}$ & $\mathrm{EC}$ & $\mathrm{C}^{2}$ & $\mathrm{H}$ & $\mathrm{N}$ & $\mathrm{S}$ & $\begin{array}{r}\mathrm{H} / \mathrm{C} \\
\text { atomic } \\
\text { ratio }\end{array}$ & $\begin{array}{r}\text { Surface } \\
\mathrm{area}^{2} \\
\left(\mathrm{~m}^{2} \mathrm{~g}^{-1}\right)\end{array}$ & $\begin{array}{r}\text { Pore } \\
\text { volume } \\
\left(\mathrm{cm}^{3} \mathrm{~g}^{-1}\right)\end{array}$ \\
\hline $\mathrm{H}-200-2$ & 4.42 & 0.98 & 37.82 & 4.82 & 0.34 & 0.05 & 1.53 & 14.6 & 0.034 \\
$\mathrm{H}-200-4$ & 4.34 & 1.01 & 39.83 & 4.51 & 0.40 & 0.04 & 1.36 & 19.4 & 0.056 \\
H-200-6 & 4.19 & 1.02 & 40.81 & 4.31 & 0.44 & 0.04 & 1.27 & 20.7 & 0.064 \\
H-200-8 & 4.22 & 1.01 & 42.6 & 4.17 & 0.50 & 0.08 & 1.17 & 21.5 & 0.076 \\
H-200-12 & 4.33 & 0.99 & 44.08 & 4.06 & 0.53 & 0.01 & 1.11 & 22.6 & 0.092 \\
H-200-16 & 4.35 & 0.98 & 43.13 & 3.83 & 0.53 & 0.02 & 1.07 & 29.7 & 0.128 \\
H-300-2 & 3.41 & 1.18 & 41.87 & 2.97 & 0.62 & 0.01 & 0.85 & 14.5 & 0.065 \\
H-300-4 & 3.43 & 1.23 & 42.43 & 3.55 & 0.64 & 0.06 & 0.84 & 24.9 & 0.082 \\
H-300-6 1 & 3.41 & 1.35 & 45.56 & 3.2 & 0.69 & 0.04 & 0.84 & 20.3 & 0.074 \\
H-300-8 & 3.41 & 1.17 & 46.01 & 3.26 & 0.75 & 0.03 & 0.85 & 19.1 & 0.069 \\
H-300-12 & 3.46 & 1.34 & 46.19 & 3.26 & 0.75 & 0.03 & 0.85 & 23.3 & 0.073 \\
H-300-16 & 3.43 & 1.36 & 47.32 & 3.13 & 0.74 & 0.04 & 0.79 & 18.7 & 0.049 \\
\hline
\end{tabular}

1 These samples were selected for further analyses.

2 Average values of triplicate measurements.

yields decrease as the temperature is raised from 200 to $300^{\circ} \mathrm{C}$. This decrease is closely connected with deoxygenating reactions (e.g. dehydration, decarboxylation) and volatile matter conversion, as the oxygen and hydrogen contents become lower at higher temperatures (Table 2). The hydrochar yields obtained from the hydrothermal carbonization are in the $66-58 \mathrm{wt} \%$ range at $200^{\circ} \mathrm{C}$ and $66-36 \mathrm{wt} \%$ at $300^{\circ} \mathrm{C}$. At both temperatures, it can be seen that after $6 \mathrm{~h}$ of treatment, the yield remains somewhat constant. This indicates that any major transformations and structural rearrangements do occur in the first $6 \mathrm{~h}$, after which the products became structurally stable. Gao et al. (2013) and He et al. (2013) observed the same trend during the production of hydrochars from water hyacinth and sewage sludge, respectively. The values of carbon content and surface area were used as reference points for the reproducibility of the production method. At each temperature and residence time, triplicate samples were measured in terms of carbon content and surface area, and the relative standard deviation was found to be 9 and $6 \%$, respectively.

The hydrothermal treatment of rice husk led to an increase in the carbon content of the solid residue from $36.1 \%$ (rice husk, Table 1) to 43 and $47 \%$ in the case of H-200-16 and H-300-16, respectively (Table 2). This shows that the rice husk was only partially carbonized during the process. The increasing trend at $300^{\circ} \mathrm{C}$ suggests that a more complete carbonization of the product can be achieved at longer residence times. The $\mathrm{H} / \mathrm{C}$ atomic ratio decreased steadily with time, at $200{ }^{\circ} \mathrm{C}$ (from 1.53 to 1.07 ). At $300^{\circ} \mathrm{C}$, in the first $12 \mathrm{~h}$ the ratio is practically the same and only after $16 \mathrm{~h}$ a small decline was observed. This indicates that at the higher temperature the structural rearrangements and reaction pathways occur at a faster rate and the product becomes stable in a smaller amount of time. Therefore, temperature has a more predom- inant role than time during hydrochar production. This behaviour is consistent with the formation of a well-condensed material, especially at $300^{\circ} \mathrm{C}$ (Sevilla and Fuertes, 2009).

The $\mathrm{pH}$ values were acidic, approximately 4.4 and 3.4 for the 200 and $300^{\circ} \mathrm{C}$ hydrochars respectively. Electrical conductivity was slightly increased with temperature, from a mean of $1 \mathrm{mS} \mathrm{cm}^{-1}$ at $200^{\circ} \mathrm{C}$ to a mean of $1.2 \mathrm{mS} \mathrm{cm}^{-1}$ at $300^{\circ} \mathrm{C}$, indicating high salinity for all samples.

Surface areas and pore volumes were low and very similar for all hydrochar samples. The slightly increasing trend at $200^{\circ} \mathrm{C}$ can be attributed to the surface roughness because the pore volume remains practically the same (Unur et al., 2013). Based on the yield, residence time and surface area, two hydrochar samples were selected for further analyses. Since the yield remains nearly constant after the $6 \mathrm{~h}$ mark and surface area is practically the same for all samples at both temperatures, H-200-6 and H-300-6 were selected for further tests. It is important to remember that hydrothermal treatment is an energy-consuming process; thus reducing treatment time may have a positive economic effect when scaling-up occurs.

Table 3 shows the results obtained from the analyses of H-200-6 and H-300-6, where an important influence of temperature can be observed. Volatile matter significantly decreased from 43.06 to $15.1 \mathrm{wt} \%$ in H-200-6 and H-300-6, respectively. With respect to fixed carbon, it increased from $29.43 \%$ in $\mathrm{H}-200-6$ to $46.57 \%$ in $\mathrm{H}-300-6$, indicating polymerization/condensation reactions during treatment of rice husk at $300^{\circ} \mathrm{C}$. These results were similar to those obtained during pyrolysis of wastes (Méndez et al., 2013). High fixed carbon recoveries (108 and $113 \%$ for the selected samples at 200 and $300^{\circ} \mathrm{C}$, respectively) were obtained. Considering the principle of mass conservation, this indicates that the decrease of volatile matter at the higher temperature is converted to other products, probably $\mathrm{CO}_{2}$ and other gases 
Table 3. Properties of hydrochar samples H-200-6 and H-300-6.

\begin{tabular}{lll}
\hline & $\mathrm{H}-200-6$ & $\mathrm{H}-300-6$ \\
\hline Volatile organic content VM (\%) & 43.06 & 15.10 \\
Fixed carbon content FC (\%) & 29.43 & 46.57 \\
Fixed carbon recovery (\%) & 108 & 113 \\
Ash content $(\%)$ & 24.54 & 40.14 \\
Micropore area $\left(\mathrm{m}^{2} \mathrm{~g}^{-1}\right)$ & 0.8714 & 1.0036 \\
$\mathrm{HHV}$ predicted $\left(\mathrm{MJ} \mathrm{kg}^{-1}\right)$ & 15.7 & 17.8 \\
$\mathrm{O}(\%)^{1}$ & 29.86 & 10.37 \\
$\mathrm{Cu}\left(\mathrm{mg} \mathrm{kg}^{-1}\right)$ & $\mathrm{nd}$ & $\mathrm{nd}$ \\
$\mathrm{Ni}\left(\mathrm{mg} \mathrm{kg}^{-1}\right)$ & $\mathrm{nd}$ & $\mathrm{nd}$ \\
$\mathrm{Cd}\left(\mathrm{mg} \mathrm{kg}^{-1}\right)$ & $\mathrm{nd}$ & $\mathrm{nd}$ \\
$\mathrm{Zn}\left(\mathrm{mg} \mathrm{kg}^{-1}\right)$ & 0.80 & 1.32 \\
$\mathrm{~Pb}\left(\mathrm{mg} \mathrm{kg}^{-1}\right)$ & $\mathrm{nd}$ & $\mathrm{nd}$ \\
\hline
\end{tabular}

1 calculated by difference

2 non-detected

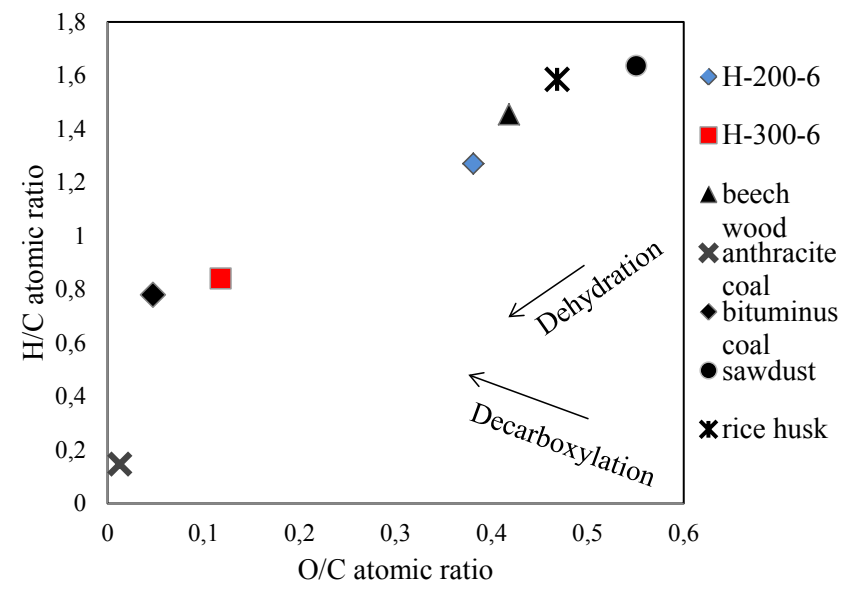

Figure 2. Van Krevelen diagram showing the position of H-200-6 and H-300-6 hydrochars among known fuels and biomass materials.

(Kang et al., 2012). Furthermore, it is worth mentioning that, at the end of hydrothermal process, once the reactor has cooled down, there is only a slight overpressure inside the vessel, which suggests that a small number of gaseous products are generated during hydrothermal carbonization. The heavy metal contents after acid digestion were below detection limit, except for $\mathrm{Zn}^{2+}$, which increased a $65 \%$ with temperature as compared to biochars obtained by conventional pyrolysis (Méndez et al., 2012).

The atomic $\mathrm{H} / \mathrm{C}$ and $\mathrm{O} / \mathrm{C}$ ratios were calculated using the elemental composition data. Results from this analysis are presented in a Van Krevelen diagram (Fig. 2). Van Krevelen diagrams allow for delineation of reaction pathways and offer a clear insight into the chemical transformations of the carbon-rich material, which are demethanation (production of methane), dehydration (production of water) and decarboxylation (production of carbonyls including carboxylic acids). Figure 2 shows that both the $\mathrm{H} / \mathrm{C}$ and $\mathrm{O} / \mathrm{C}$ ratios de-

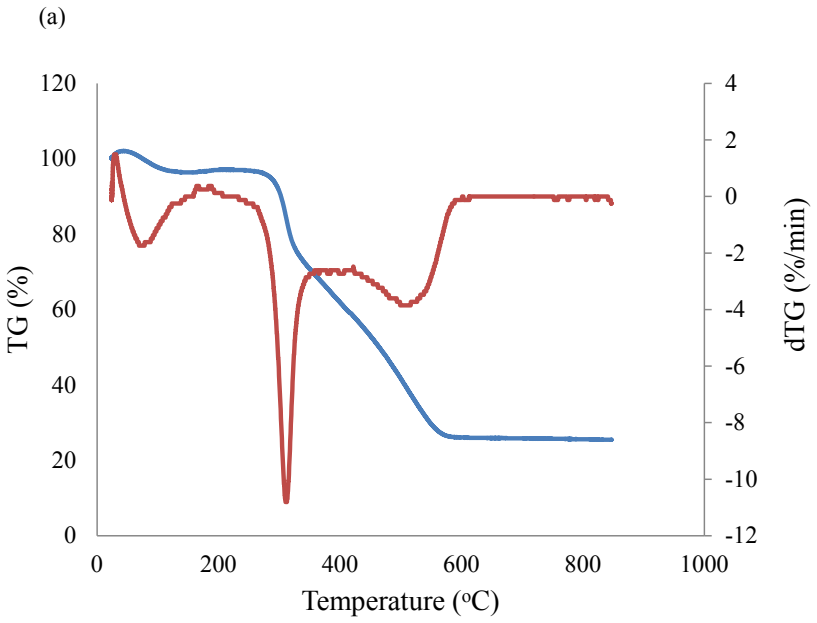

(b)

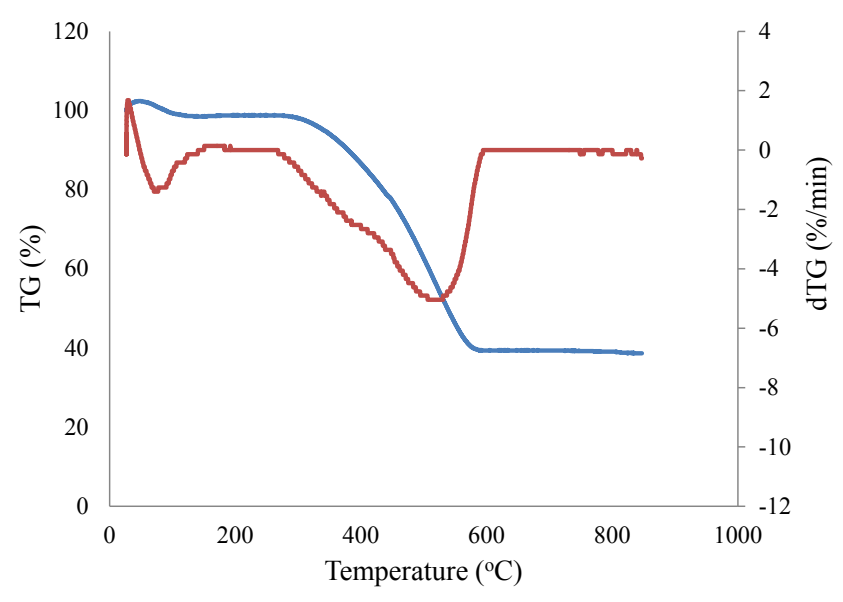

Figure 3. TG-dTG curves for the combustion profiles of (a) H-2006 and (b) H-300-6.

creased when the temperature was raised. At high temperature operation, the dehydration path is predominant as compared to the lower temperature operation. It is suggested that a side reaction, which is decarboxylation, occurs during the hydrothermal process because a complete dehydration reaction removes water molecules from the samples ( $\mathrm{Lu}$ et al., 2013; Falco et al., 2011a, 2011b; Parshetti et al., 2013). Toor et al. (2011) provide a comprehensive review on the basic reaction pathways involved in the hydrothermal conversion of the main biomass components (carbohydrates, lignin, protein and lipids) to bio-products. The Van Krevelen diagram suggests an improvement in the fuel properties from the $\mathrm{H}-200$ 6 to the H-300-6 sample. This is confirmed by the predicted HHVs, which indicate a $11.8 \%$ increase as the temperature is raised from 200 to $300^{\circ} \mathrm{C}$ (15.7 and $17.8 \mathrm{MJ} \mathrm{kg}^{-1}$ for the H-200-6 and H-300-6, respectively). These values are comparable to the calorific value of lignite $\left(16.3 \mathrm{MJ} \mathrm{kg}^{-1}\right)$ and are in good agreement with those measured by Liu et al. (2014) for a range of hydrochars. As suggested by Danso-Boateng et 


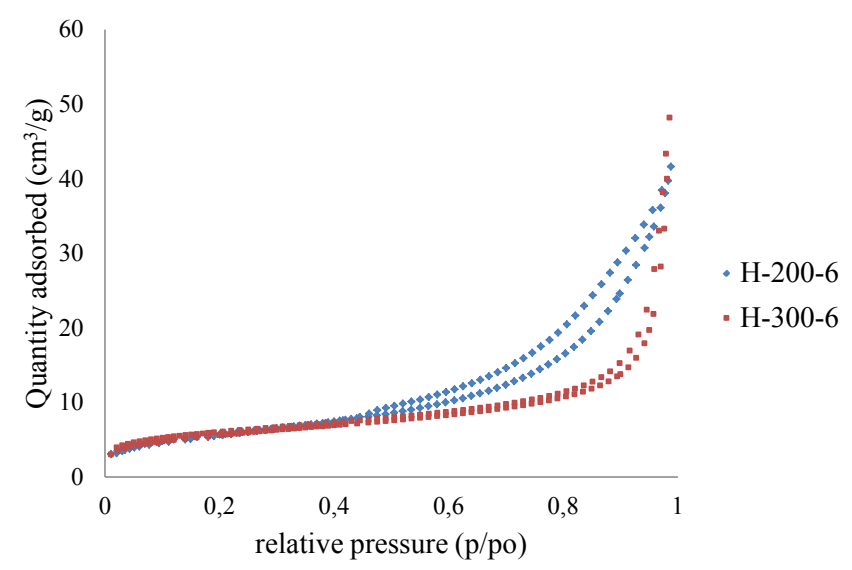

Figure 4. Nitrogen adsorption and desorption isotherms for H-2006 and $\mathrm{H}-300-6$.

al. (2013), energy densification of the hydrochars occurs as a result of decreases in solid mass caused by the dehydration and decarboxylation reactions.

The combustion profiles of H-200-6 and H-300-6 are shown in Fig. 3. At temperatures lower than $150{ }^{\circ} \mathrm{C}$, weight loss corresponds to water release from the samples. Then, from 200 to $600{ }^{\circ} \mathrm{C}$, weight loss was related to volatilization and combustion of organic matter. The dTG curve of H-2006 showed three distinctive bands: the first related to humidity release at temperatures lower than $150^{\circ} \mathrm{C}$; the second band with a maximum at $310^{\circ} \mathrm{C}$ was typical of cellulose combustion; and finally the third band with maximum weight loss at $\sim 520^{\circ} \mathrm{C}$ could be related to combustion of more polymerized organic matter. Comparing with the H-300-6 curve, the peak related to the presence of cellulose diminishes considerably whereas the peak at $\sim 520^{\circ} \mathrm{C}$ slightly increases.

Figure 4 shows the $\mathrm{N}_{2}$ isotherms for H-200-6 and H-3006. In both cases the isotherms could be classified as type II according to the IUPAC classification. Type II isotherms are typically obtained in cases of non-porous or macroporous materials, where unrestricted monolayer-multilayer adsorption can occur. Improvements in the porosity of hydrochars and the surface area are therefore necessary to enable their use as adsorbents of contaminants, hydrogen storage or electrical energy storage (supercapacitors). Such improvements have been achieved with a combination of thermal and chemical activation methods (Sevilla et al., 2011b).

\section{Conclusions}

Rice husk was treated in subcritical water (hydrothermal carbonization) in order to obtain hydrochars. A safe and simple to set up and operate system was used, consisting of a stainless steel reactor, caps and a source of heat. Two sets of hydrochars were obtained, corresponding to experimental temperatures of 200 and $300^{\circ} \mathrm{C}$ and residence times in the range of $2-16 \mathrm{~h}$. The carbon contents of the products increased with temperature, whereas the hydrogen and oxygen contents decreased. The surface area was low for all hydrochars, indicating that porous structure was not developed during treatment. Of the two hydrochars tested further (H-200-6 and H-300-6), the latter showed improved fuel properties as indicated by the Van Krevelen diagram and the predicted higher heating value. However, the high ash content of hydrochars from rice husk should be taken into consideration when such materials are to be used as fuels, due to potential slagging or fouling of boiler tubes and corrosion of metal surfaces. Since additional steps (such as activation) are required to increase the surface area - and therefore the adsorption capacity - of the hydrochars, their production for fuel purposes may be a more suitable pathway. The fact that hydrothermal carbonization takes place in an aqueous reaction medium means that wet biomass can be used, thus eliminating any energy-consuming pre-drying steps before treatment. An additional advantage is that unlike dry pyrolysis, any gaseous emissions produced during hydrothermal carbonization are largely dissolved in the char-water slurry. For this reason, hydrothermal carbonization is more flexible and has fewer technical considerations. However, there is still need for a full characterization of the acetone- and water-soluble fractions of hydrochars, in order to determine any undesirable by-products.

Edited by: J. Paz-Ferreiro

\section{References}

Abel, S., Peters, A., Trinks, S., Schonsky, H., Facklam, M., and Wessolek, G.: Impact of biochar and hydrochar addition on water retention and water repellency of sandy soil, Geoderma, 202203, 183-191, 2013.

Bargmann, I., Rillig, M. C., Buss, W., Kruse, A., and Kuecke, M.: Hydrochar and biochar effects on Germination of Spring Barley, J. Agron. Crop Sci., 199, 360-373, 2013.

Busch, D., Stark, A., Kammann, C. I., and Glaser, B.: Genotoxic and phytotoxic risk assessment of fresh and treated hydrochar from hydrothermal carbonization compared to biochar from pyrolysis, Ecotox. Environ. Safe., 97, 59-66, 2013.

Channiwala, S. A. and Parikh, P. P.: A unified correlation for estimating HHV of solid, liquid and gaseous fuels, Fuel, 81, 10511063, 2002.

Danso-Boateng, E., Holdich, R. G., Shama, G., Wheatley, A. D., Sohail, M., and Martin, S. J.: Kinetics of faecal biomass hydrothermal carbonisation for hydrochar production, Appl. Energ., 111, 351-357, 2013.

Daskalaki, V. M., Timotheatou, E. S., Katsaounis, A., and Kalderis, D.: Degradation of Reactive Red 120 using hydrogen peroxide in subcritical water, Desalination, 274, 200-205, 2011.

Ding, L., Zou, B., Li, Y., Liu, H., Wang, Z., Zhao, C., Su, Y., and Guo, Y.: The production of hydrochar-based hierarchical porous 
carbons for use as electrochemical supercapacitor electrode materials, Colloids Surfaces A, 423, 104-111, 2013a.

Ding, L., Zou, B., Liu, H., Li, Y., Wang, Z., Su, Y., Guo, Y., and Wang, X.: A new route for conversion of corncob to porous carbon by hydrolysis and activation, Chem. Eng. J., 225, 300-305, 2013b.

Falco, C., Baccile, N., and Titirici, M.-M.: Morphological and structural differences between glucose, cellulose and lignocellulosic biomass derived hydrothermal carbons, Green Chem., 13, 32733281, 2011a.

Falco, C., Caballero, F. P., Babonneau, F., Gervais, C., Laurent, G., Titirici, M. M., and Baccile, N.: Hydrothermal carbon from biomass: structural differences between hydrothermal and pyrolyzed carbons via ${ }^{13} \mathrm{C}$ solid state NMR, Langmuir, 27, 1446014471, $2011 b$.

Gao, Y., Wang, X., Wang, J., Li, X., Cheng, J., Yang, H., and Chen, H.: Effect of residence time on chemical and structural properties of hydrochar obtained by hydrothermal carbonization of water hyacinth, Energy, 58, 376-383, 2013.

Gajić, A. and Koch, H.-J.: Sugar beet (Beta vulgaris L.) growth reduction caused by hydrochar is related to nitrogen supply, J. Environ. Qual., 41, 1067-1075, 2012.

He, C., Giannis, A., and Wang, J.-Y.: Conversion of sewage sludge to clean solid fuel using hydrothermal carbonization: hydrochar fuel characteristics and combustion behaviour, Appl. Energ., 111, 257-266, 2013.

Jamari, S. S. and Howse, J. R.: The effect of the hydrothermal carbonization process on palm oil empty fruit bunch, Biomass Bioenergy, 47, 82-90, 2012.

Kalderis, D., Hawthorne, S. B., Clifford, A. A., and Gidarakos, E.: Interaction of soil, water and TNT during degradation of TNT on contaminated soil using subcritical water, J. Hazard. Mater., 159, 329-334, 2008.

Kang, S., Li, X., Fan, J., and Chang, J.: Characterization of hydrochars produced by hydrothermal carbonization of lignin, cellulose, D-xylose, and wood meal, Indust. Engin. Chem. Res., 51, 9012-9023, 2012.

Liu, Z., Quek, A., Kent Hoekman, S., and Balasubramanian, R.: Production of solid biochar fuel from waste biomass by hydrothermal carbonization, Fuel, 103, 943-949, 2013.

Liu, Z., Quek, A., and Balasubramanian, R.: Preparation and characterization of fuel pellets from woody biomass, agro-residues and their corresponding hydrochars, Appl. Energ., 113, 13151322,2014

Lu, X., Pellechia, P. J., Flora, J. R. V., and Berge, N. D.: Influence of reaction time and temperature on product formation and characteristics associated with the hydrothermal carbonization of cellulose, Bioresource Technol., 138, 180-190, 2013.
Méndez, A., Gómez, A., Paz-Ferreiro, J., and Gascó, G.: Effects of sewage sludge biochar on plant metal availability after application to a Mediterranean soil, Chemosphere, 89, 1354-1359, 2012.

Méndez, A., Terradillos, M., and Gascó, G.: Physicochemical and agronomic properties of biochar from sewage sludge pyrolysed at different temperatures, J. Anal. Appl. Pyrol., 102, 124-130, 2013.

Parshetti, G. K., Kent Hoekman, S., and Balasubramanian, R.: Chemical, structural and combustion characteristics of carbonaceous products obtained by hydrothermal carbonization of palm empty fruit bunches, Bioresource Technol., 135, 683-689, 2013.

Sevilla, M. and Fuertes, A. B.: The production of carbon materials by hydrothermal carbonization of cellulose, Carbon, 47, 22812289, 2009.

Sevilla, M., Macia-Agullo, J. A., and Fuertes, A. B.: Hydrothermal carbonization of biomass as a route for the sequestration of $\mathrm{CO}_{2}$ : chemical and structural properties of the carbonized products, Biomass Bioen., 35, 3152-3159, 2011a.

Sevilla, M., Fuertes, A. B., and Mokaya, R.: High density hydrogen storage in superactivated carbons from hydrothermally carbonized renewable organic materials, Energ. Environ. Sci., 4, 1400-1410, 2011b.

Toufiq Reza, M., Lynam, J. G., Helal Uddin, M., and Coronella, C. J.: Hydrothermal carbonization: fate of inorganics, Biomass Bioen., 49, 89-94, 2013.

Toor, S. S., Rosendahl, L., and Rudolf, A.: Hydrothermal liquefaction of biomass: A review of subcritical water technologies, Energy, 36, 2328-2342, 2011.

Unur, E., Brutti, S., Panero, S., and Scrosati, B.: Nanoporous carbons from hydrothermally treated biomass as anode materials for lithium ion batteries, Micropor. Mesopor. Mat., 174, 25-33, 2013.

USEPA: Method 3051a: Microwave Assisted Acid Dissolution of Sediments, Sludges, Soils and Oils, $2^{\circ}$ edn., US Gov. Print Office, Washington, USA, 1997.

Wagner, A. and Kaupenjohann, M.: Suitability of biochars (pyroand hydrochars) for metal immobilization on former sewagefield soils, Eur. J. Soil Sci., 65, 139-148, 2014.

Wiedner, K., Naisse, C., Rumpel, C., Pozzi, A., Wieczorek, P., and Glaser, B.: Chemical modification of biomass residues during hydrothermal carbonization - What makes the difference, temperature or feedstock?, Org. Geochem., 54, 91-100, 2013. 